\title{
Daily Diet of Pelobates fuscus (Pelobatidae, Amphibia) in the Khoper River Floodplain (Saratov Region)
}

\author{
Mikhail V. Yermokhin ${ }^{1 凶}$, https://orcid.org/0000-0001-6377-6816; ecoton@rambler.ru \\ Vasily G. Tabachishin ${ }^{2}$, https://orcid.org/0000-0002-9001-1488; tabachishinvg@sevin.ru \\ ${ }^{\prime}$ Saratov State University \\ 83 Astrakhanskaya St., Saratov 410012, Russia \\ ${ }^{2}$ Saratov Branch of A. N. Severtsov Institute of Ecology and Evolution, Russian Academy of Sciences \\ 24 Rabochaya St., Saratov 410028, Russia
}

Received 16 June 2020, revised 12 July 2020, accepted 11 August 2020

\begin{abstract}
The daily diet of Pelobates fuscus in local populations in the Khoper river floodplain is considered. The absence of gender differences in their daily diet is shown. Most of $P$. fuscus prey is made up of animals weighing 10-25 mg and having body lengths of $8-18 \mathrm{~mm}$. Hymenoptera $(70.8 \%)$ and Coleoptera $(52.1 \%)$ predominate by the number of specimens and by biomass, respectively. The number of daily caught invertebrates usually does not exceed 15 . The lowest feed consumption is in April and October, while the highest one is in the summer months.

Keywords: common spadefoot toad, diet, gender differences.
\end{abstract}

DOI: https://doi.org/10.18500/1814-6090-2020-20-3-4-152-155

This article is an open access article distributed under the terms and conditions of the Creative Commons Attribution 4.0 License

The common spadefoot toad (Pelobates fuscus (Laurenti, 1768)), among the amphibians leading a terrestrial lifestyle, is one of the most common in the northern Lower Volga region (Shlyakhtin et al., 2005; Yermokhin et al., 2018). It occurs on the edges of deciduous and mixed forests, agrocenoses, steppe open areas, where it prefers places with sandy and sandyloamy soil (Shlyakhtin et al., 2005; Yermokhin et al., 2015). However, despite the wide distribution of $P$. fuscus in the region, some aspects of its nutritional ecology remain poorly studied as yet. In addition, the literature data on the amount of food consumed and the amount of the daily diet of $P$. fuscus are contradictory and very generalized (Aleynikova, Utrobina, 1951; Medvedev, 1974; Shcherbak, Shcherban', 1980; Garanin, 1983; Gorbunov, 1989; Ruchin et al., 2007; Cogalniceanu et al., 1998; Tobias et al., 2001; Nicoara et al., 2005; Covaciu-Marcov et al., 2010; Buhaciuc et al., 2017).

Nutritional studies of $P$. fuscus are based on the analysis of stomach contents samples. Collections were carried out in the floodplain of the Khoper River (environs of Letyazhevka village, Arkadak district) from the second half of April till mid-October in 2002 - 2003. Amphibians were caught in the evening and at night (from $10 \mathrm{pm}$ to $2 \mathrm{am}$ ) on standard sites using grooves with trapping cylinders. The sample size was 41 specimens, including 8 ones with empty stomachs.
The body length $(S V L)$ of captured $P$. fuscus specimens was measured with a caliper with an accuracy of $0.1 \mathrm{~mm}$. The live weight of females was estimated by weighing them on an electronic balance KERN CM60-2N with an accuracy of $0.01 \mathrm{~g}$.

The contents of the stomach were extracted by washing with water, after which the amphibians were released into the wild (Pisarenko, Voronin, 1976). The stomach contents were analyzed in laboratory conditions. During office processing, the entire contents of the stomach were weighed first. Then the sample was handsorted: each food component was identified, weighed on an electronic balance KERN ABT 120-5DM with an accuracy of $0.1 \mathrm{mg}$, and measured. The identification of food items was carried out mainly to the species level, when the identification was difficult, the item was attributed to one or another family or order.

The normality of the sample distribution was checked by the Shapiro-Wilk criterion $(W)$. Most of the samples had a significant deviation from the normal distribution $(p<0.05)$; therefore, when describing them, the median $(\mathrm{Me})$ and interquartile range (25-75 percentiles) were used as descriptive statistics parameters. Comparison of the size-weight and trophological indicators was carried out using the MannUtney test $(U)$. Differences were considered significant when $p<0.05$. Statistical processing of the material was performed by the PAST 2.17 software package (Hummer et al., 2001). 


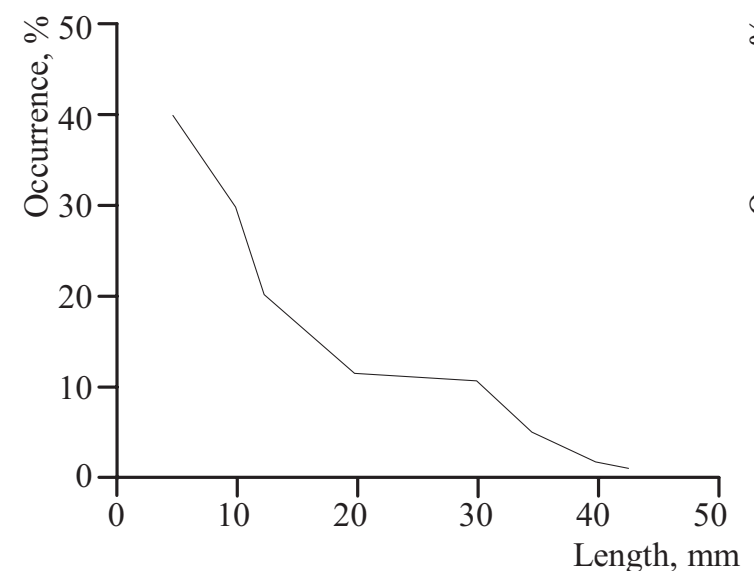

$\boldsymbol{a}$

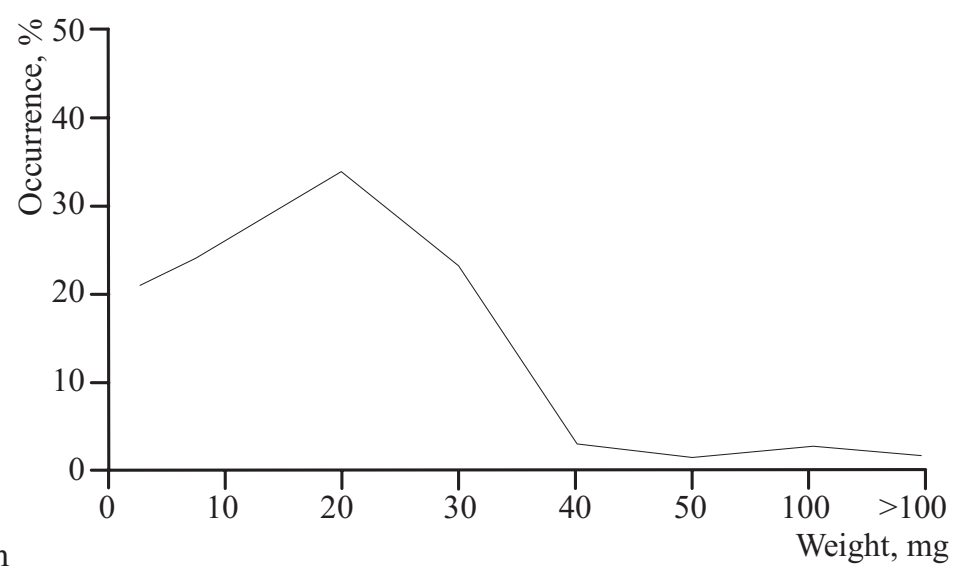

b

Figure. Length $(a)$ and weight $(b)$ of objects in the prey of Pelobates fuscus

In the course of our work, it was found that in the conditions of the study area, most of the P. fuscus prey is made up of animals weighing 10-25 $\mathrm{mg}$ and having body lengths within $8-18 \mathrm{~mm}$ (Figure). Obviously, such prey body sizes are the most optimal for P. fuscus.

Our comparison of the stomach contents of males and females shows no statistically significant differences in the amount and volume of food between the sexes $(p>0.05)$. However, males had a slightly larger weight of food items per stomach on average, but these differences were not statistically significant (Table). In addition, the food composition of males was more various. Obviously, these differences are due to the relatively large size of the male head, as well as their greater mobility.

Hymenoptera (70.8\%) and Coleoptera (52.1\%) predominated by the number of specimens in stomachs and the frequency of occurrences, and by biomass, respectively. Notable role in the diet is played by Orthoptera and Arachnida. Lepidoptera and Coleoptera larvae, Hemiptera nymphs and adults were also found in the stomach contents.

Table. Size-weight characteristics and daily diet of Pelobates fuscus (July, 2003)

\begin{tabular}{|c|c|c|c|}
\hline \multirow[b]{2}{*}{ Indicator } & \multicolumn{2}{|c|}{ Sex* } & \multirow[b]{2}{*}{$\frac{U}{p}$} \\
\hline & $\begin{array}{c}\hat{\sigma} \hat{O} \\
N=14\end{array}$ & $\begin{array}{c}\text { 웅 } \\
N=19\end{array}$ & \\
\hline$S V L, \mathrm{~mm}$ & $45.8-54.3$ & $52.0 \frac{53.0}{-56.0}$ & $<\underline{\underline{6.0}}$ \\
\hline$W_{\text {live }}, \mathrm{g}$ & $11.68-13.53$ & $\frac{16.30}{15.5-17.7}$ & $\frac{71.5}{\mathbf{0 . 0 3}}$ \\
\hline Number of food items, ind. & $\underline{7-10}$ & $\frac{8}{7-10}$ & $\frac{132.0}{0.97}$ \\
\hline Food lump weight, $g$ & $0.3 \frac{0.425}{43-0.550}$ & $0.3 \frac{0.350}{300-0.600}$ & $\frac{103.0}{0.27}$ \\
\hline
\end{tabular}

Note. ${ }^{*}$ - The numerator is the median; the denominator is the interquartile range.
The daily number of invertebrates caught by spadefoot toads was small: it rarely exceeded 15 specimens. At the same time, we previously found that the value of the daily diet was less variable in the amphibians caught at the same time and more labile during the active period (Shlyakhtin et al., 2007). The lowest level of feed consumption is typical for April and October, when spadefoot toads kill 7-8 victims and utilize $230-240 \mathrm{mg}$ of biomass per day.

In May and June, the feed consumption gradually increases and peaks in July. In August, and under favorable weather and climatic conditions in September as well, the level of feed consumption, although it decreases in comparison with July, may remain quite high. From the second half of September to October, the feed consumption decreases significantly.

Thus, the food composition of $P$. fuscus is quite diverse and is largely determined by the seasonal dynamics of the victim fauna in the habitats. The largest amount of feed is consumed by $P$. fuscus during the summer months.

\section{REFERENCES}

Aleynikova M. M., Utrobina N. M. The Role of Amphibians in Ecosystems Shelterbelt Forest Plantations. Zoologichesky zhurnal, 1951, vol. 30, no. 3, pp. 391-397 (in Russian).

Buhaciuc E., Szekely P., Bancila R., Cogalniceanu Dan. Food Availability Influences Postmetamorphic Growth in Two Spadefoot Toad Species (Genus Pelobates). Amphibia - Reptilia, 2017, vol. 38, iss. 1, pp. 41-48. DOI: https://doi.org/10.1163/ 15685381-00003082

Cogalniceanu D., Aioanei F., Ciubuc C., Vadineanu A. Food and Feeding Habits in a Population of Common Spadefoot Toads (Pelobates fuscus) from an Island in the Lower Danube Floodplain. Alytes, 1998, vol. 15, pp. 145-157.

Covaciu-Marcov S.-D., Cupşa D., Ferenți S., David A., Dimancea N. Human Influence or Natural 
Differentiation in Food Composition of four Amphibian Species from Histria Fortress, Romania? Acta Zoologica Bulgarica, 2010, vol. 62, no. 3, pp. 307-313.

Garanin V. I. Zemnovodnye i presmykaiushchiesia Volzhsko-Kamskogo kraia [Amphibians and Reptiles of Volga-Kama Region]. Moscow, Nauka Publ., 1983. 175 p. (in Russian).

Gorbunov E. P. On the Ecology of the Common Spadefoot Toad, Pelobates fuscus, in the Moscow Region. In: Zemnovodnye $i$ presmykaiushchiesia Moskovskoi oblasti [Amphibians and Reptiles of Moscow Region]. Moscow, Nauka Publ., 1989, pp. 133-141 (in Russian).

Hammer O., Harper D. A. T., Ryan P. D. PAST: Palaeontological Statistics Software Packege for Education and Data Analysis. Palaeontological Electronica, 2001, vol. 4, no. 1, pp. 1-9.

Medvedev S. I. Data on Study of Amphibians' Food in the Region of the Middle Flow of the Seversky Donets River. Vestnik Zoologii, 1974, no. 1, pp. 50-59 (in Russian).

Nicoara A., Nicoara M., Bianchini F. Diet Composition During Breeding Period in Populations of Bufo viridis, Pelobates fuscus and Rana esculenta Complex from Ciric River's Basin (Iaşi, Romania). Biologie Animală, 2005, T. 51, pp. 179-187.

Pisarenko S. S., Voronin A. A. Bloodless Method for Studying the Feeding of Anuran Amphibians. Russian J. of Ecology, 1976, no. 6, pp. 87-90.

Ruchin A. B., Chikhlyaev I. V., Lukiyanov S. V., Ryzhov M. K. Feeding Habits of Local Populations of Common Spadefoot Toad (Pelobates fuscus) in the Volga and Don Basin. Povolzhskiy J. of Ecology, 2007, no. 3, pp. 265-270 (in Russian).

Shcherbak N. N., Shcherban' M. I. Zemnovodnye $i$ presmykaiushchiesia Ukrainskikh Karpat [Amphibians and Reptiles of the Ukrainian Carpathians]. Kiev, Naukova Dumka Publ., 1980. 266 p. (in Russian).

Shlyakhtin G. V., Tabachishin V. G., Zavialov E. V., Tabachishina I. E. Fauna of Saratov Region: Amphibians and Reptiles. Saratov, Izdatel'stvo Saratovskogo universiteta, 2005. 116 p. (in Russian).

Shlyakhtin G. V., Tabachishin V. G., Zavialov E. V. Seasonal Diet Variability of Common Spadefoot Toad, Pelobates fuscus, in the Northern Lower-Volga Region. Current Studies in Herpetology, 2007, vol. 7, iss. 1-2, pp. 117-123 (in Russian).

Tobias M., Romanowsky T., Larink O. Effects of the Spatial Pattern of the Habitat on the Feeding Efficacy for the Common Spade Foot Toad (Pelobates fuscus). Agriculture, Ecosystems and Environment, 2001, vol. 84, iss. 2, pp. 187-190.

Yermokhin M. V., Tabachishin V. G., Ivanov G. A. Spawning Migration Phenology of the Spadefoot Toad Pelobates fuscus (Pelobatidae, Amphibia) in the Valley of the Medveditsa River (Saratov Oblast). Biology Bulletin. 2015. Vol. 42, iss. 10, pp. 931-936. DOI: https:// doi.org/10.1134/S1062359015100040

Yermokhin M. V., Ivanov G. A., Tabachishin V. G. Structure Transformation of the Anuran Amphibian Spawning Communities in Floodplain Lakes of the Medveditsa River Valley (Saratov Region) under Conditions of LongTerm Reduction of Water Content. Povolzhskiy J. of Ecology, 2018, no. 4, pp. 404-417. DOI: https://doi.org/10.18500/ 1684-7318-2018-4-404-417

\section{Cite this article as:}

Yermokhin M. V., Tabachishin V. G. Daily Diet of Pelobates fuscus (Pelobatidae, Amphibia) in the Khoper River Floodplain (Saratov Region). Current Studies in Herpetology, 2020, vol. 20, iss. 3-4, pp. 152-155. DOI: https://doi.org/10.18500/1814-6090-2020-20-3-4-152-155 


\author{
Особенности суточной диеты Pelobates fuscus (Pelobatidae, Amphibia) \\ в пойме р. Хопёр (Саратовская область) \\ М. В. Ермохин ${ }^{1 凶}$, В. Г. Табачишин ${ }^{2}$ \\ ${ }^{1}$ Саратовский национальный исследовательский государственный университет \\ имени Н. Г. Чернышевского \\ Россия, 410012, Саратов, Астраханская, 83 \\ ${ }^{\square}$ E-mail: ecoton@rambler.ru \\ ${ }^{2}$ Саратовский филиал Института проблем экологии и эволюичии им. А. Н. Северцова РАН \\ Россия, 410028, Саратов, Рабочая, 24 \\ E-mail: tabachishinvg@sevin.ru \\ Поступила в редакцию 16.06.2020 г., после доработки 12.07.2020 г., принята 11.08.2020 г.
}

\begin{abstract}
Аннотация. Рассмотрена суточная диета Pelobates fuscus в локальных популяциях в пойме р. Хопёр. Показано отсутствие половых различий в суточной диете. Большую часть добычи составляют животные массой 10 25 мг и длиной тела $8-18$ мм. По числу экземпляров доминируют перепончатокрылые (Hymenoptera) (70.8\%), а по биомассе - жесткокрылые (Coleoptera) (52.1\%). Число ежесуточно добываемых беспозвоночных обычно не превышает 15 экз. Самый низкий уровень потребления кормов - в апреле и октябре, наибольший в летние месяцы.

Ключевые слова: чесночница обыкновенная, диета, половые различия.
\end{abstract}

DOI: https://doi.org/10.18500/1814-6090-2020-20-3-4-152-155

\title{
Образец для цитирования:
}

Yermokhin M. V., Tabachishin V. G. Daily Diet of Pelobates fuscus (Pelobatidae, Amphibia) in the Khoper River Floodplain (Saratov Region) [Ермохин М. В., Табачишин В. Г. 2020. Особенности суточной диеты Pelobates fuscus (Pelobatidae, Amphibia) в пойме р. Хопёр (Саратовская область)] // Современная герпетология. Т. 20, вып. 3/4. С. 152 - 155. DOI: https://doi.org/ 10.18500/1814-6090-2020-20-3-4-152-155 